\title{
Implementation of a Design Procedure for the Project of a Flexible Pavement in a Military Installation
}

\author{
Fernando Jove Wilches ${ }^{1}$, Jorge Luis Argoty Burbano² and Fabián Andrés García Pabón ${ }^{3}$ \\ ${ }^{1}$ Department of Civil Engineering, Universidad de Sucre, Sincelejo, Sucre, Colombia. \\ ${ }^{2}$ Department of Civil Engineering, Universidad de Nariño, San Juan de Pasto, Nariño, Colombia. \\ ${ }^{3}$ Rocales \& Concretos S.A.S, Santiago de Cali, Valle del Cauca, Colombia.
}

ORCIDs: 0000-0002-2080-4036 (Fernando), 0000-0001-6661-1398 (Jorge), 0000-0001-8799-2804 (Fabián)

\begin{abstract}
In the present work, a procedure is carried out for the design of flexible-type structure pavements in a military installation, for which the particularities related to the typical traffic along the roads and access areas have been taken into consideration of these entities, within Colombian territory. For the modeling of the pavement structures, three design methodologies were used: the AASHTO method (Version 1993), the MS-23 Manual "Thickness Design Asphalt Pavements for Heavy Wheel Loads", developed by the North American Asphalt Institute for the design of flexible pavements with heavy loads, and the software Pavement-Transportation Computer Assisted Structural Engineering PCASE developed by the Transportation Systems Center \& Engineering Research and Development Center of US Army Corps Engineers. According to the results obtained, it was possible to determine the typical sections of pavement structures made up of asphalt folder and granular base, for two different conditions of bearing capacity of the subgrade; these designs, which can be implemented for the solution of pavements in military installations within the Colombian territory
\end{abstract}

Keywords: flexible pavement, design, military installation, pavement modelling

\section{INTRODUCTION}

The theoretical foundation for pavement design involves different methodologies, from which they are based on empirical relationships, where the in situ performance of pavements is correlated through observations and field measurements, considering traffic loads, environmental conditions., the characteristics of the soil, the quality of the materials and the construction processes, up to those that are based on the elastic multilayer design, for which the state of stresses and deformations of the layers of the structure, are decisive to be able to predict the behavior from the pavement. This last approach has been facilitated with the development of computer programs such as ALIZE, ELSYM5, BISAR, KENLAYER, among others [1].

With regard to traffic, in the case of the pavement project in a military installation, the physical conformation of the vehicle axles, the load application radius, as well as the load that a single axle can apply on the structure, it can easily exceed the effect generated by the standard design axle used in the AASHTO methodology (1993), which corresponds to a single axle double wheel weighing 8.2 tons [2]. On the other hand, although the frequencies of traffic in a military installation are normally low, the damage caused to the pavement can be relatively high, for which a particular study is required, in order to obtain more reliable designs and adjusted to the actual demanding conditions to which the structure will be exposed.

To carry out the study, it was first necessary to carry out an inventory of the different existing military vehicles in Colombia, in order to characterize said traffic and obtain the typical design vehicle, taking into account the frequency of use and the most critical loads, both in magnitude and in its tire configuration. Once the design vehicle had been chosen, the pavement structures were modeled through three different design methodologies: AASHTO Method (1993) [2], Manual MS-23 "Thickness Design Asphalt Pavements for Heavy Wheel Loads", from the North American Institute of asphalt [3]; and PCASE software for airport and highway pavement design, which considers military vehicles [4].

\section{MATERIALS AND METHODS}

For the present investigation, three flexible pavement design methods were selected, for whose implementation, the use of materials that comply with the specifications and regulations in force in Colombia is recommended [5], [6]. The methods used were: The AASHTO method (VERSION 1993), which corresponds to the most used empirical design model in the country (According to Montejo, 2002) [7]; the MS-23 Manual "Thickness Design Asphalt Pavements for Heavy Wheel Loads", developed by the North American Asphalt Institute for the design of flexible pavements with heavy loads, which uses the elastic multilayer theory with its own transfer equations for the calculation of the thickness; and the software PavimentoTransporte Computer-aided structural engineering PCASE developed by the Transportation Systems Center \& Engineering Research and Development Center of US Army Corps Engineers in 2010, which adopts a multilayer elastic model and has the special condition of being able to characterize the variable transit with military vehicles [4]. 


\section{II.I AASHTO method (Version 1993)}

The AASHO road trial conducted near Ottawa, Illinois, during the period 1958-1962, has been the largest field experiment in traffic simulation to date, and became the basis for design guidelines used in North America. Said test was carried out for a traffic of 1'000,000 repetitions and based on the results obtained, the equations were interpolated and the recommendations that gave rise to the AASHTO method for flexible pavement design were generated [2]. This methodology focuses on the determination of the so-called structural number (SN) required, through which, a combination of thicknesses of the different layers of the structure must be provided, in such a way that their work together, be capable of supporting the requested load level.

For the determination of the required structural number, the AASHTO-93 method provides the following equation:

$$
\log _{10} W t 18=Z_{R} * S_{o}+9.36 * \log _{10}(S N+1)-0.20+\frac{\log _{10}\left[\frac{\Delta P S I}{4.2-1.5}\right]}{0.40+\frac{1094}{(S N+1)^{5.19}}}+2.32 * \log _{10} M_{R}-8.07
$$

From the knowledge of the required structural number, the thicknesses of the different layers are determined, starting from equation (2).

$\mathrm{SN}=\left(\mathrm{a}_{1}\right)\left(\mathrm{D}_{1}\right)+\left(\mathrm{a}_{2}\right)\left(\mathrm{m}_{2}\right)\left(\mathrm{D}_{2}\right)+\left(\mathrm{a}_{3}\right)\left(\mathrm{m}_{3}\right)\left(\mathrm{D}_{3}\right)$

\section{II.II Asphalt Institute MS-23 Manual}

This method is used in the design of asphalt pavement thicknesses for heavy vehicles, such as log haulage trucks, dump trucks, forklift trucks, forklifts, rubber-tire forklifts and many other specialty vehicles that are supported on four to twelve or more tires. Some of these vehicles have gross masses (weights) greater than 180,000 kilograms (400,000 lb). Many have wheel loads and tire spacing characteristics that do not allow the use of standard design methods [3].

The design procedure is based on multilayer elastic design concepts. This approach assumes that applying a load to the pavement produces two critical elastic stresses: horizontal tensile stress, $\varepsilon$ t, in the bottom of the asphalt concrete layer; and vertical compressive stress, $\varepsilon$ c, at the top of the subgrade layer. Design criteria, in terms of maximum allowable values, have been established and are used as the basis for selecting the appropriate thickness, TA, of a full or full depth asphalt pavement [3].

The procedure is based on the concept that multi-wheeled vehicle pavement design can be achieved by first calculating an "equivalent" single wheel load. The equivalent single wheel load is used to select the pavement thickness. Pavement thickness will vary with ground contact pressures with the vehicle tire, the magnitude of the load, and the spacing of the loaded tires [3].

In addition to the characteristics of the vehicle and the load, the design thickness of the asphalt pavement will depend on the resistance of the subgrade and the annual average air temperature.
In this procedure, the basic design analysis is given in terms of a single wheel load of some magnitude, $\mathrm{P}$, and ground-tire contact pressure, q. However, many vehicles have multiple wheels located close enough to each other so that the influence of combined loads is taken into account. This is done by calculating an equivalent single wheel load to represent the multiple wheel condition. The combined influence of the adjacent wheels is determined by using interface deflection factors. Deflections are calculated at the subgrade surface, under multiple wheel load, and an equivalent single wheel load is determined that will produce equal deflection. The equivalent wheel load is then used to design the pavement [3].

The number of deformation repetitions is relatively small for typical design situations for military installations, compared to highway designs, which are designed for horizontal extensible deformations, being generally thinner than required by compression deformation criteria vertical. For this reason, and to reduce the complexity of the design procedure, the criterion of vertical subgrade deformation is used in the development of the design method proposed for this study.

\section{II.III Multilayer elastic system}

Based on the conformation of pavements that have several layers of different materials, it is necessary to consider them within the theory of multilayer systems. This has generated a great deal of work for the analysis of stresses and deformations in multilayer systems, in which the following assumptions are established [8]:

- Each layer is made up of materials that are isotropic, homogeneous and weightless.

- The system acts as a composite system, that is, there is a continuity of the stresses or deformations through the interfaces, depending on the assumptions made about their state [8].

- Most of the solutions assume that the materials are linearly elastic [8] [9].

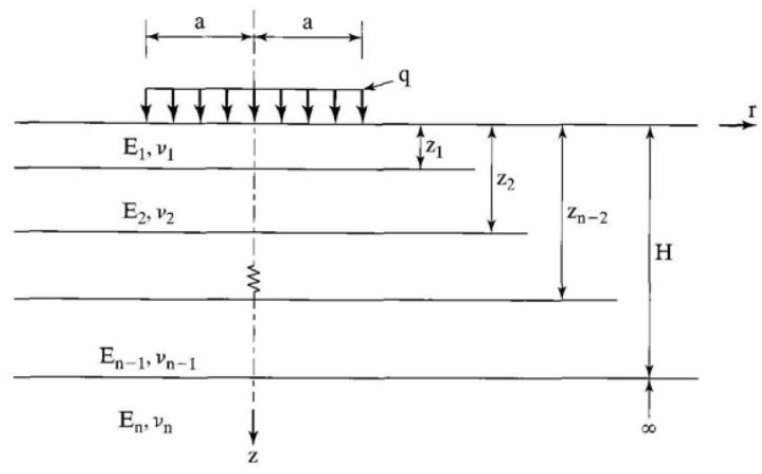

Fuente. "Pavement Analysis and Design" de Yang H. Huang

Fig. 1. Elastic multilayer system

Figure 1 shows a system of n-layers in cylindrical coordinates, the $n$-th layer being of infinite thickness (Appendix B of the book "Pavement Analysis and Design" by Yang H. Huang). 
Due to the complexity of the distribution of loads and configurations to which the sections of a pavement are subjected, a possible solution to the model was proposed, through the use of the total number of equivalent simple axle loads (ESALs). This approach converts wheel loads of various magnitudes and mixed traffic repetitions into an equivalent number of reference standard axles, with the most common load used being an 18,000 pound dual-tire single axle. Axle load equivalence factors are used to describe the relative amount of damage generated by a given load, corresponding to a given axle configuration, with respect to that generated by the standard reference load. For multilayer elastic systems, two failure mechanisms of the pavement structure are proposed: fatigue cracking in the lower fiber of the asphalt layer and rutting due to permanent deformation in the subgrade [8] (Professor Huang presents in his book Pavimet Analysis and Desing).

For the development of this work, the PCASE software was used, which works under the multilayer elastic system and allows the design of pavements for both airfields and road stops. The PCASE tool provides the engineer with the ability to perform pavement designs quickly and thus the ability to make timely decisions, with precision and consistency.

\section{II.IV Selection of Design Method}

For the selection of the design method, three aspects were taken into account: the first is that the model was traditional and widely used in conventional flooring; For this purpose, the AASHTO (1993) method was selected; The second aspect is associated with the high loads that military vehicles have and which can be higher than those established in traditional methodologies, for which the pavement design manual for heavy loads, Manual MS-23, was selected. "Thickness Design Asphalt Pavements for Heavy Wheel Loads"; Finally, a method or tool was sought that took into account the specific variables of the design and it was found that the PCASE computer-aided structural engineering software Pavimento-Transporte considers the configuration and specific loads of military vehicles.

\section{II.V Definition of traffic for design}

For design purposes, regarding the expected traffic, the following conditions were adopted, based on the existing military vehicles in Colombia.

Table 1. Characterization of the traffic for the conditions of analysis

\begin{tabular}{|c|c|c|c|c|}
\hline $\begin{array}{c}\text { TIPO DE } \\
\text { TRÁNSITO }\end{array}$ & TIPO DE VEHICULOS & CARGAS & $\begin{array}{c}\text { \#PASADAS } \\
\text { CALCULADA }\end{array}$ & $\begin{array}{l}\text { \#PASADAS } \\
\text { ASUMIDA }\end{array}$ \\
\hline $\begin{array}{c}\text { Vehiculo } \\
\text { Militar Tipo }\end{array}$ & ISBI MRAP KODIAK & $\begin{array}{l}\text { Una Carga Tipo } \\
\text { Neumatico }\end{array}$ & 101.731 & 100.000 \\
\hline \multirow{8}{*}{$\begin{array}{l}\text { Vehiculos } \\
\text { Militares }\end{array}$} & \multirow{3}{*}{$\begin{array}{l}\text { ENGESA EE-9 CASCAVEL } \\
\text { ENGESA EE-11 URUTU } \\
\text { ISBI MRAP KODIAK }\end{array}$} & \multirow{3}{*}{$\begin{array}{l}\text { \#de Pasadas } \\
\text { Neumaticos }\end{array}$} & 71.679 & 70.000 \\
\hline & & & 23.893 & 25.000 \\
\hline & & & 23.893 & 25.000 \\
\hline & TPM-113 & $\begin{array}{c}\text { \#de Pasadas } \\
\text { Orugas }\end{array}$ & 101.731 & 100.000 \\
\hline & \multirow{4}{*}{$\begin{array}{c}\text { ISBI MRAP KODIAK } \\
\text { ENGESA EE-9 CASCAVEL } \\
\text { ENGESA EE-11 URUTU } \\
\text { TPM-113 }\end{array}$} & \multirow{4}{*}{$\begin{array}{l}\text { \# de Pasadas } \\
\text { Neumáticos y } \\
\text { Orugas }\end{array}$} & 23.893 & 25.000 \\
\hline & & & 23.893 & 25.000 \\
\hline & & & 23.893 & 25.000 \\
\hline & & & 23.893 & 25.000 \\
\hline
\end{tabular}

For design purposes, the ISBI MRAP KODIAK was taken as a typical vehicle, as it has the highest frequency of passage and generates the highest loads. This vehicle corresponds to a C2P truck, armored and with a maximum combat weight of 13.2 Tons.

Table 2. Typical vehicle for design

\begin{tabular}{|c|c|c|c|c|}
\hline $\begin{array}{c}\text { TIPO DE } \\
\text { TRANSITO }\end{array}$ & TIPO DE VEHICULOS & CARGAS & $\begin{array}{c}\text { "PASADAS } \\
\text { CALCCLADA }\end{array}$ & $\begin{array}{c}\text { \#PASADAS } \\
\text { ASUMIDA }\end{array}$ \\
\hline $\begin{array}{c}\text { Vehiculo } \\
\text { Militar Tipo }\end{array}$ & ISBI MRAP KODIAK & $\begin{array}{c}\text { Una Carga Tipo } \\
\text { Neumatico }\end{array}$ & 101.731 & 100.000 \\
\hline
\end{tabular}

\section{RESULTS AND DISCUSSION}

The modeling of the structure was carried out considering two categories, regarding the bearing capacity of the subgrade, one for CBR of $5 \%$ and the other for CBR of $10 \%$.

Table 3. Design thicknesses for $\mathrm{CBR}=5 \%$

\begin{tabular}{|c|c|c|c|c|c|}
\hline \multicolumn{2}{|c|}{ Método AASHTO 93 } & \multicolumn{2}{c|}{ Manual MS-23 } & \multicolumn{2}{c|}{ PCASE } \\
\hline CAPA & $\begin{array}{c}\text { ESPESOR } \\
(\mathbf{c m})\end{array}$ & CAPA & $\begin{array}{c}\text { ESPESOR } \\
(\mathbf{c m})\end{array}$ & CAPA & $\begin{array}{c}\text { ESPESOR } \\
(\mathbf{c m})\end{array}$ \\
\hline Carpeta asfáltica & 10 & Carpeta asfáltica & 55 & Carpeta asfáltica & 9 \\
\hline Base Granular & 20 & & & Base Granular & 26 \\
\hline CBR subrasante & $5 \%$ & CBR subrasante & $5 \%$ & CBR subrasante & $5 \%$ \\
\hline
\end{tabular}

Table 4. Design thicknesses for $\mathrm{CBR}=10 \%$

\begin{tabular}{|c|c|c|c|c|c|}
\hline \multicolumn{2}{|c|}{ Método AASHTO 93 } & \multicolumn{2}{c|}{ Manual MS-23 } & \multicolumn{2}{c|}{ PCASE } \\
\hline CAPA & $\begin{array}{c}\text { ESPESOR } \\
(\mathbf{c m})\end{array}$ & CAPA & $\begin{array}{c}\text { ESPESOR } \\
(\mathbf{c m})\end{array}$ & CAPA & $\begin{array}{c}\text { ESPESOR } \\
(\mathrm{cm})\end{array}$ \\
\hline Carpeta asfáltica & 10 & Carpeta asfáltica & 45 & Carpeta asfáltica & 9 \\
\hline Base Granular & 12 & & & Base Granular & 13 \\
\hline CBR subrasante & $10 \%$ & CBR subrasante & $10 \%$ & CBR subrasante & $10 \%$ \\
\hline
\end{tabular}

According to what is observed in Tables 3 and 4, very similar thicknesses are presented between the AASHTO method and the PCASE software, where the structure is made up of an asphalt layer and a granular base. Meanwhile, the thicknesses obtained through the MS-23 Manual are quite high, due to the load considerations established by this model.

For the definition of the design thicknesses using the PCASE software, different forms of the contact footprint of the tires were analyzed, to finally take a representative value of the thicknesses in each case. In tables 5 and 6 , you can see the results obtained for different geometries of the contact area, for the case of the two categories of CBR considered for design.

Table 5. PCASE software thicknesses for $\mathrm{CBR}=5 \%$ and different forms of the contact mark

\begin{tabular}{|c|c|c|c|c|c|c|c|}
\hline \multicolumn{10}{|c|}{ PCASE } \\
\hline DEFECTO Shape1.652 & \multicolumn{2}{|c|}{ ELIPSE Shape 0.5 } & \multicolumn{2}{|c|}{ CIRCULAR Shape 1.0 } & \multicolumn{2}{c|}{ ELIPSE Shape 2.0 } \\
\hline Capa & $\begin{array}{c}\text { Espesor } \\
\text { Cm }\end{array}$ & Capa & $\begin{array}{c}\text { Espesor } \\
\text { Cm }\end{array}$ & Capa & $\begin{array}{c}\text { Espesor } \\
\text { Cm }\end{array}$ & Capa & $\begin{array}{c}\text { Espesor } \\
\text { Cm }\end{array}$ \\
\hline Carpeta asfáltica & 8.9 & Carpeta asfáltica & 8.9 & Carpeta asfáltica & 8.9 & Carpeta asfáltica & 8.9 \\
\hline Base Granular & 25.7 & Base Granular & 26.6 & Base Granular & 26.2 & Base Granular & 25.6 \\
\hline CBR subrasante & 5 & CBR subrasante & 5 & CBR subrasante & 5 & CBR subrasante & 5 \\
\hline
\end{tabular}


Table 6. PCASE software thicknesses for $\mathrm{CBR}=10 \%$ and different forms of the contact mark

\begin{tabular}{|c|c|c|c|c|c|c|c|}
\hline \multicolumn{7}{|c|}{ PCASE } \\
\hline \multicolumn{2}{|c|}{ DEFECTO Shape 1.652 } & \multicolumn{2}{|c|}{ ELIPSE Shape 0.5 } & \multicolumn{2}{|c|}{ CIRCULAR Shape 1.0 } & \multicolumn{2}{c|}{ ELIPSE Shape 2.0 } \\
\hline Capa & $\begin{array}{c}\text { Espesor } \\
\mathrm{Cm}\end{array}$ & Capa & $\begin{array}{c}\text { Espesor } \\
\mathrm{Cm}\end{array}$ & Capa & $\begin{array}{c}\text { Espesor } \\
\text { Cm }\end{array}$ & Capa & $\begin{array}{c}\text { Espesor } \\
\mathrm{Cm}\end{array}$ \\
\hline Carpeta asfältica & 8.9 & Carpeta asfältica & 8.9 & Carpeta asfältica & 8.9 & Carpeta asfältica & 8.9 \\
\hline Base Granular & 12.7 & Base Granular & 13.2 & Base Granular & 13 & Base Granular & 12.6 \\
\hline CBR subrasante & 10 & CBR subrasante & 10 & CBR subrasante & 10 & CBR subrasante & 10 \\
\hline
\end{tabular}

From the results shown in Tables 5 and 6 , it can be observed that the thicknesses obtained in each case through the PCASE software, for the different forms of the contact marks, are substantially the same.

Finally, for construction purposes, Table 7 is presented, which proposes the typical flexible pavement design that is recommended to be implemented in the case of military installations in Colombia.

Table 7. Summary of the performance of ML algorithms

\begin{tabular}{|l|c|c|}
\hline LAYER & \multicolumn{2}{|c|}{ THICKNESSES $(\mathrm{cm})$} \\
\hline Asphalt concrete & 10 & 10 \\
\hline Granular base & 25 & 15 \\
\hline Subgrade CBR & $5 \%$ & $10 \%$ \\
\hline
\end{tabular}

\section{CONCLUSION}

According to the results obtained in the present study, it has been possible to determine a typical flexible structure design for pavements along access roads or within military installations located within Colombian territory, taking into account two categories of Support floor, that is, for support layers with CBR of $5 \%$ and CBR of $10 \%$.

\section{REFERENCES}

[1] Leiva, P., Loría, L.G., and Navas, A., Comparación entre modelación de respuestas de pavimentos flexibles con análisis de multicapa elástica, y elemento finito, XVI CILA Congreso Ibero-Latinoamericano del Asfalto, Rio Janeiro, Brasil, 2011.

[2] American Association of state Highway Transportation Officials - AASHTO-93. Guide for design of pavement Structures. Washington D.C.

[3] Asphalt Institute. . Thickness Design Asphalt Pavements for Heavy Wheel Loads, Manual. USA: Series No 23 (MS23). 2006.

[4] US Army Corps Engineers, Transportation Systems Center \& Engineering Research and Development Center. PCASE2.09, Pavement-Transportation Computer Assisted Structural Engineering, User Manual. USA., 2010.

[5] Instituto Nacional de Vías, Especificaciones Generales de Construcción de Carreteras, Ministerio de Transporte, Bogotá, Colombia, 2013.

[6] Instituto Nacional de Vías, Normas de Ensayo de Materiales, Ministerio de Transporte, Bogotá, Colombia, 2013.
[7] A. Montejo, "Ingeniería de pavimentos", 3th edition, Universidad Católica de Colombia, Bogotá, 2016.

[8] C. Castillo, "Revisión de los métodos de diseño de pavimentos flexibles "AASHTO93" y el "MODELO ELASTICO LINEAL (KENLAYER)”, mediante el modelo Viscoelástico propuesto por la "ME PDG NCHRP 1-37A (3D-MOVE)", Universidad Nacional de Colombia, Medellín, Colombia, 2014.

[9] Y. Huang, "Pavement analysis and design, Apéndice B", University of Kentucky, New Jersey, 2004. 